\title{
Kajian Potensi Pemakaman sebagai Ruang Terbuka Hijau Perkotaan Studi Kasus: TPU Kota Pontianak
}

\author{
Agustiah Wulandari \\ Program Studi Perencanaan Wilayah dan Kota, Fakultas Teknik Universitas Tanjungpura, Indonesia \\ wulandari.agustiah@gmail.com
}

\begin{abstract}
ABSTRAK
Ruang terbuka hijau (RTH) pada saat ini banyak mengalami perubahan fungsi menjadi lahan terbangun. Tidak dipungkiri lagi bahwa RTH di banyak kota di Indonesia sudah beralih fungsi menjadi kawasan pemukiman, perhotelan, restauran, pertokoan, perkantoran, jalan raya, tempat parkir, pompa bensin, tempat pedagang kaki lima dan kawasan lainnya. Hal ini menciptakan kelangkaan RTH di banyak daerah perkotaan di Indonesia. Proses perencanaan kota yang berwawasan lingkungan sangat diperlukan di seluruh wilayah perkotaan di Indonesia. Pemanfaatan ruang terbuka yang selama ini belum atau kurang dimanfaatkan harus lebih dimaksimalkan lagi pemanfaatannya, seperti tempat pemakaman. Pemakaman merupakan salah satu bentuk ruang terbuka kota yang belum efektif pemanfaatannya sebagai RTH. Karakteristik dan jenis makam yang ada di Indonesia seperti tempat pemakaman umum (TPU) dan tempat pemakaman khusus (TPK) memiliki kelebihan dan kekurangan untuk dimanfaatkan sebagai ruang terbuka hijau. Pemanfaatan tempat pemakaman umum sebagai RTH dilakukan dengan membandingkan variabel-variabel dari tiap indikator fungsi RTH, seperti fungsi sosial, fungsi fisik, dan fungsi estetika. Kesimpulan yang dihasilkan berdasarkan fungsi fisik RTH kawasan pemakaman saat ini masih belum ada kawasan pemakaman umum yang secara optimal dapat berfungsi sebagai RTH. Kawasan Pemakaman yang memenuhi fungsi sosial RTH adalah TPU Islam, TPU Kristen, dan TPU tionghoa. Sedangkan Fungsi estetika RTH dapat dipenuhi oleh tempat pemakaman Kristen dan Tionghoa.
\end{abstract}

Kata kunci: tempat pemakaman, ruang terbuka hijau

\begin{abstract}
Green open space has now been changed into buildings. urban green space has been converted into residential areas, hotels, restaurants, shops, offices, highways, parking lots, gas stations, street vendors and other areas. This creates a dearth of green space in many urban areas in Indonesia. Ecological city planning is indispensable in all urban areas in Indonesia. Utilization of open space should be maximized ecologically. Cemetery is one of the urban open space that has not been effectively utilized as a green space. Characteristics cemetery in Indonesia as a public cemetery and the private cemetery have advantages and disadvantages for use as green open space. Analysis of the utilization of public cemeteries as open green space is done by comparing the variables of each indicator function of green open space, such as a social function, physical function, and aesthetic functions. The resulting conclusion is that no area of the public cemetery that optimally meets the physical function as green open space. Cemetery area which fulfills a social function of green open space is the Islamic cemetery, Christian cemetery, and Chinese cemetery. While the aesthetic function can be fulfilled by Christian Cemetery dan Tionghoa cemetery.
\end{abstract}

Keywords: cemetery, green open space

\section{Pendahuluan}

Kota merupakan pusat konsentrasi kegiatan. Pertumbuhan penduduk yang meningkat dan konsentrasi kegiatan seperti, pemerintahan, perkantoran, perdagangan, komersial dan jasa. Pertumbuhan aktivitas kota mengakibatkan intensitas penggunaan lahan di pusat kota menjadi sangat tinggi.
Seiring dengan perkembangan aktifitas penduduk tersebut menyebabkan lahan yang tersedia lebih difokuskan kepada penyediaan lahan untuk pemukiman penduduk serta kegiatan perekonomian. Peralihan fungsi lahan menyebabkan penurunan kualitas lingkungan perkotaan, yang dapat diartikan kota hanya maju di bidang ekonomi tetapi mundur secara 
ekologi. Terganggunya kestabilan ekosistem perkotaan akan menyebabkan peningkatan suhu udara di perkotaan, penurunan air tanah, banjir/genangan, intrusi air laut, abrasi pantai, pencemaran air yang berupa air minum berbau dan mengandung logam berat, pencemaran udara seperti meningkatnya kadar $\mathrm{CO}$, ozon, karbondioksida, oksida nitrogen, dan belerang, debu, suasana yang gersang, monoton, bising, dan kotor.

Keberadaaan

ruang

terbuka khususnya ruang terbuka publik di pusat kota (terutama ruang terbuka hijau kota) sangat dibutuhkan, karena fungsi dan peranannya sebagai tempat pertemuan masyarakat untuk bersosialisasi antar sesama, sebagai tempat beristirahat dari kesibukan serta sebagai paru-paru kota. Masyarakat kota yang cenderung hidup dengan jadwal yang padat membutuhkan suatu tempat untuk melepaskan kepenatan Masyarakat perlu berhubungan dengan sesamanya dan ruang publik merupakan sarana bagi masyarakat untuk bersosialisasi maupun sekedar melepas lelah. Ruang terbuka publik yang dimaksud dalam studi ini adalah ruang terbuka hijau (RTH).

RTH saat ini banyak mengalami perubahan menjadi lahan terbangun (Aswad, 2004: 59). Tidak dipungkiri lagi bahwa RTH di banyak kota di Indonesia sudah beralih fungsi menjadi kawasan pemukiman, perhotelan, restauran, pertokoan, perkantoran, jalan raya, tempat parkir, pompa bensin, tempat pedagang kaki lima dan kawasan lainnya. Semua kawasan dimaksud mengubah RTH menjadi peruntukan lain sehingga menciptakan kelangkaan RTH di banyak daerah perkotaan di Indonesia. Kondisi RTH yang memprihatinkan tersebut membatasi ruang gerak masyarakat dan mengurangi kemampuan lingkungan mereduksi pencemar. Hal ini dapat menyebabkan gangguan kesehatan dan kejiwaan bagi anak-anak, remaja, orangtua dan bahkan manula karena mereka tidak mempunyai ruang gerak yang memadai.

Oleh karena itu, sangat dibutuhkan proses perencanaan pembangunan kota yang berwawasan lingkungan di seluruh wilayah perkotaan di Indonesia. Dengan pemanfaatan ruang terbuka yang selama ini belum atau kurang dimanfaatkan harus lebih dimaksimalkan lagi pemanfaatannya, seperti tempat pemakaman. Tempat pemakaman merupakan salah satu bentuk RTH kota yang belum efektif pemanfaatannya sebagai RTH. Hal ini selaras dengan Instruksi Menteri Dalam Negeri Nomor 14 Tahun 1988 tentang Penataan Ruang Terbuka Hijau di Wilayah Perkotaan dan diperbaharu dalam Peraturan Menteri Dalam Negeri Nomor 1
Tahun 2007 tentang Penataan Ruang Terbuka Hijau Kawasan Perkotaan, "Keberadaan TPU harus ada dan tetap dipertahankan di tengah-tengah kehidupan kota metropolitan. Sebab menurut Eko Budhiharjo ${ }^{1}$, pemakaman merupakan komponen utama dalam siklus kehidupan kota, condition sine qua non, syarat mutlak yang tidak bisa ditawar-tawar"Selain itu, tempat pemakaman harus dilihat sebagai aset, potensi, dan investasi kota jangka panjang, sebagai tujuan ekowisata kota dan layanan kremasi yang sehat dan ramah lingkungan (nilai ekonomi), makam bersejarah orang-orang terkenal dan ruang spiritual warga kota, serta taman konservasi kota, yang terbukti mampu mendanai keberlanjutan pemeliharaan dan pengembangan makam.

Melihat kondisi RTH di Indonesia yang semakin kritis, alternatif yang tepat untuk penanggulangan kondisi tersebut adalah dengan memanfaatkan RTH pemakaman. Pemakaman belum dimanfaatkan keindahan maupun fungsinya sebagai $R T H$ secara efektif untuk menciptakan iklim udara kota yang sejuk dan nyaman. Ruang terbuka pemakaman saat ini hanya berbentuk lahan kosong atau ruang terbuka dengan beberapa jenis tata hijau tanaman.

Tempat pemakaman di Indonesia dibedakan menjadi beberapa jenis, yaitu: Tempat Pemakaman Umum (TPU) yang ditujukan untuk masyarakat umum yang penggolongannya dibedakan berdasarkan agama yang dianut. Setiap agama memiliki aturan tersendiri untuk mengatur lahan pemakaman. Pemanfaatannya sebagai lahan terbuka hijau tidak sama dalam masing-masing pemakaman. Selain itu, terdapat juga Tempat Pemakaman Khusus (TPK) yang biasanya berupa Taman Makam Pahlawan. Setiap jenis makam tersebut memiliki kelebihan dan kekurangan untuk dimanfaatkan sebagai ruang terbuka hijau

Tulisan ini bertujuan untuk mengidentifikasi potensi pemanfaatan kawasan pemakaman sebagai RTH. Untuk mencapai tujuan tersebut, ditentukan sasaran studi yaitu:

a. Merumuskan fungsi Ruang Terbuka Hijau (RTH)

b. Merumuskan indikator dan variabel RTH

c. Mengidentifikasi keadaan kawasan pemakaman yang dijadikan studi kasus.

d. Menganalisis pemanfaatan kawasan pemakaman studi kasus berdasarkan fungsi RTH.

e. Mengetahui permasalahan dan kendala dalam pemanfaatan kawasan

\footnotetext{
1 Budiharjo, Eko. 2003. Artikel dengan judul Krisis Lahan Pembangunan yang Kritis. Harian Kompas, 8 Juli 2003
} 
pemakaman secara umum sebagai RTH berdasarkan studi kasus yang dilakukan.

f. Mengidentifikasi pemanfaatan kawasan sebagai RTH.

\section{Ruang Terbuka Hijau dan Tempat Pemakaman Umum (TPU)}

Identifikasi terhadap pemanfaatan Kawasan Pemakaman sebagai RTH Bertujuan untuk mengetahui kendalakendala yang ada dalam pemanfaatan kawasan pemakaman sebagai ruang terbuka hijau serta potensi yang perlu dikembangkan agar pemnfaatan kawasan pemakaman sebagai ruang terbuka hijau memperoleh hasil yang maksimal.

\section{Pengertian dan Fungsi RTH}

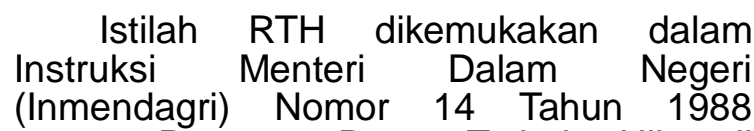
tentang Penataan Ruang Terbuka Hijau di wilayah perkotaan dan diperbaharui dalam Peraturan Menteri Dalam Negeri Nomor 1 Tahun 2007 tentang Penataan Ruang Terbuka Hijau Kawasan Perkotaan. Dijelaskan dalam Inmendagri ini bahwa pengertian ruang terbuka adalah ruangruang dalam kota atau wilayah lain yang lebih luas, baik dalam bentuk area/kawasan maupun dalam bentuk memanjang/jalur dimana dalam penggunaannya lebih bersifat terbuka dan pada dasarnya tanpa bangunan. RTH sendiri adalah ruang terbuka yang di dalam pemanfaatannya didominasi oleh pengisian hijau tanaman atau tumbuh-tumbuhan secara alamiah ataupun budidaya tanaman seperti lahan pertanian, pertamanan, perkebunan dan sebagainya.

Menurut fungsinya, RTH dapat dibedakan menjadi 3 (tiga) fungsi, yaitu: fungsi sosial, fungsi fisik, dan fungsi estetika yang dapat dijelaskan di bawah ini:

\section{Fungsi Sosial}

Fungsi secara sosial merupakan suatu fungsi yang mampu menggambarkan ekspresi budaya lokal, RTH merupakan media komunikasi warga kota, tempat rekreasi, tempat pendidikan, dan penelitian. Selain itu, RTH merupakan fasilitas umum atau berfungsi umum dengan indikator sebagai berikut :

a. Kemudahan (accessible)

- Kemudahan fisik (physical acces), yaitu apakah ruang terbuka tersebut tersedia untuk publik, apakah ada batasan fisik pada ruang terbuka seperti pagar, gerbang atau penjaga gerbang atau harus melewati tangga untuk mencapai kawasan, yang berarti tidak terbuka bagi pengguna kursi roda, orang tua, dan sebagainya.

- Kemudahan visual (visual acces), yaitu apakah pengguna dapat melihat kedalam ruang terbuka dari luar, apakah mereka tahu bahwa itu adalah ruang publik ketika mereka memasukinya dengan aman dan akan diterima. Pada beberapa orang, terutama orang tua (fragile elderly persons), ruang publik dengan terlalu banyak aktifitas, seperti bermain bola mungkin kurang mudah diterima dan menyebabkan mereka merasa tidak berhak memanfatkannya.

- Kemudahan simbolis (symbolic acces), yaitu adanya elemenelemen yang membuat orang-orang atau sebagian orang merasa tidak diterima pada ruang publik tersebut. Seperti keberadaan penjaga gerbang (satpam).

b. Kebutuhan akan keamanan dan kesehatan (health \& safety)

Persoalan yang paling umum adalah bagaimana mengurangi pengaruh lingkungan atau substansi yang merugikan, dimana ancaman terhadap kesehatan dapat berupa kondisi ekstrim seperti kebisingan, panas, dingin dan sebagainya. Tanda peringatan terhadap bahaya dapat diharapkan sebagai salah satu upaya untuk mengurangi potensi gangguan keamanan manusia.

\section{c. Kenyamanan (comfort) dan Relaksasi (Relaxation) \\ Kenyamanan (comfort) yaitu ruang} terbuka publik dalam peruntukannya harus bisa memenuhi berbagai kebutuhan dasar pengguna seperti tempat beristirahat, terlindung dari sengatan matahari, tempat berolahraga dan sebagainya. Banyak sumber yang menyebabkan ketidaknyamanan orang seperti cahaya yang menyilaukan (glare), tempat duduk, kondisi udara dan sebagainya. Pada dasarnya kita lebih cenderung untuk mengurangi ketidaknyamanan dari pada menciptakan kondisi yang nyaman. Pada umumnya kenyamanan merupakan pemenuhan terhadap fungsi biologis tubuh. Fungsi ketidaknyamanan adalah untuk melindungi seseorang dari kondisi ekstrim.

Relaksasi (relaxation) sebagaimana halnya kenyamanan merupakan suatu ukuran kepuasan psikologis. Relaksasi berkaitan dengan kondisi tubuh dan pikiran yang mengalami penurunan tekanan atau paksaan dan kembali ke kondisi normal, atau perpindahan dari kondisi rutin ke kondisi lain yang lebih santai. Seperti melihat-lihat pemandangan, berjalan kaki di 
tempat yang teduh dan tenang, terhindar dari kebisingan dan lain sebagainya.

\section{d. Mendapatkan udara segar dalam lingkungan}

Dalam proses fotosintesa, energi sinar matahari diserap klorofil tanaman dan dapat melakukan langkah-langkah yang rumit dan menjadi energi ikatan-ikatan kimia yang mengikat molekul-molekul karbohidrat yang menjadi satu, dan oksigen dilepas sebagai hasil ikatan proses fotosintesa. Peristiwa ini mengakibatkan RTH yang ada dapat menciptakan oksigen dan mengurangi polutan udara yang dapat merugikan manusia (Hakim dalam Aswad, 2004: 61).

\section{e. Pembatas jarak antara massa bangunan \\ Vegetasi yang terdapat di dalam suatu} kota dapat pula digunakan sebagai penghalang pandangan terhadap hal-hal yang tidak menyenangkan untuk dilihat, seperti adanya tanah kosong yang terbengkalai, sampah, dan sebagainya. Hal ini dapat menimbulkan kesan yang baik (Hakim dalam Aswad, 2004: 61).

\section{Fungsi Fisik}

Fungsi secara fisik merupakan suatu fungsi yang memberi jaminan pengadaan RTH menjadi bagian dari sistem sirkulasi udara (paru-paru kota), pengatur iklim mikro, agar sistem sirkulasi udara dan air SIndikator ruang terbuka hijau yang mempunyai fungsi fisik adalah sebagai berikut:

a. Mengurangi polusi udara

Tanaman sebagai elemen hijau, pada pertumbuhannya menghasilkan zat asam (O2) yang sangat diperlukan bagi makhluk hidup untuk pernafasan. Mengurangi polusi udara, karena vegetasi dapat menyerap polutan. Vegetasi dapat menyaring debu dengan tajuk dan kerimbunan dedaunannya.

Selain itu, vegetasi tersebut dapat memberikan penyegaran udara.

Tanaman dapat menyerap bau secara langsung atau tanaman menahan gerakan angin yang bergerak dari sumber bau (Grey dan Deneke dalam Aswad, 2004: 66)

\section{b. Peredam bunyi}

Fungsi ini dibutuhkan dalam perkotaan karena pada umumnya aktifitas yang terjadi di perkotaan adalah aktifitas manusia yang beranekaragam seperti aktifitas kendaraan, manusia dan sebagainya. Sehingga dengan adanya ruang terbuka hijau di tengah keramaian kota dapat mengurangi tingkat kebisingan yang ditimbulkan oleh suara kendaraan (antara rumah dengan jalan). (Hakim dalam Aswad, 2004: 62).

Pohon dapat meredam suara dengan cara mengabsorpsi gelombang suara oleh daun, cabang, dan ranting. Jenis tumbuhan yang paling efektif untuk meredam suara ialah yang mempunyai tajuk yang tebal dengan daun yang rindang (Grey dan Deneke dalam Aswad, 2004: 66)

c. Pengendali angin

Vegetasi dalam suatu kota dapat digunakan sebagai pengendali angin, karena lahan kota yang luas dan vegetasi di kota pada umumnya dengan ketinggian lebih dari $2 \mathrm{~m}$. Meskipun padatnya bangunan yang ada di perkotaan tidak cukup dapat mengendali angin. Hal ini dikarenakan bangunan di perkotaan yang cukup tinggi dan kota memiliki luas lahan besar sehingga dengan adanya ruang terbuka hijau tersebut dapat mengendalikan arah angin yang berhembus kencang dan bersifat merugikan manusia (misalnya angin yang lebih banyak membawa debu atau emisi polutan udara. (Hakim dalam Aswad, 2004: 62).

Dalam mendisain ruang terbuka hijau kota untuk menahan angin faktor yang harus diperhatikan adalah:

- Jenis tanaman yang ditanam adalah tanaman yang memiliki dahan yang kuat

- Daunnya tidak mudah gugur oleh terpaan angin dengan kecepatan sedang

- Akarnya menghujam masuk ke dalam tanah. Jenis ini lebih tahan terhadap hembusan angin yang besar daripada tanaman yang akarnya bertebaran hanya disekitar permukaan tanah

- Memiliki kerapatan yang cukup (50$60 \%)$

- Tinggi dan lebar jalur hutan kota cukup besar, sehingga dapat melindungi wilayah yang diinginkan dengan baik. (Grey dan Deneke dalam Aswad, 2004: 66)

d. Menahan perkembangan lahan terbangun (sebagai penyangga)

RTH yang ditetapkan melalui peraturan daerah sebagai kawasan pemakaman sehingga keberdaannya dapat mencegah pembangunan baru khususnya di kawasan tersebut. Secara tidak langsung dapat menahan perkembangan lahan terbangun. 
e. Pengendali banjir

RTH dapat menjadi daerah resapan air hujan bagi daerah sekitarnya. Selain itu, dapat mengatasi penggenangan dengan cara daerah bawah yang sering digenangi air perlu ditanami dengan jenis tanaman yang mempunyai

kemampuan evapotranspirasi yang tinggi. Jenis tanaman yang mempunyai jumlah daun yang banyak, sehingga mempunyai stomata (mulut daun) yang banyak pula. (Dahlan dalam Aswad, 2004: 66)

\section{Fungsi Estetika}

Salah satu fungsi terpenting ruang terbuka hijau di dalam suatu kota adalah memberikan nilai estetis dan menambah kualitas lingkungan. Nilai estetis ini dapat berupa keterpaduan, proporsi, irama, serta urut-urutan. Keempat nilai ini dapat memberikan pengaruh terhadap kualitas lingkungan di perkotaan.

Nilai estetika dari tanaman diperoleh dari perpaduan antara warna (daun, batang, bunga), bentuk fisik tanaman (batang, percabangan, dan tajuk), tekstur tanaman, skala tanaman, dan komposisi tanaman. Nilai estetis tanaman dapat diperoleh dari satu tanaman, sekelompok tanaman yang sejenis, kombinasi tanaman berbagai jenis ataupun kombinasi antara tanaman dengan elemen lansekap lainnya. Nilai estetis ini meliputi:

- Warna; warna batang, daun, dan bunga dari suatu tanaman dapat menimbulkan efek visual tergantung dari refleksi cahaya yang jatuh pada tanaman tersebut

- Bentuk; bentuk tanaman dapat dimanfaatkan untuk menunjukkan bentuk dua atau tiga dimensi, memberikan kesan dinamis, indah, memperlebar, atau memperluas pandangan ataupun sebagai aksentuasi dalam suatu ruang

- Tekstur; tekstur suatu tanaman ditentukan oleh batang/percabangannya, massa daun, serta jarak penglihatan terhadap tanaman tersebut. Tekstur tanaman juga mempengaruhi secara psikis dan fisik bagi yang memandangnya.

- Skala; skala atau proporsi tanaman adalah perbandingan besaran tanaman dengan tanaman lain atau perbandingan antara tanaman dengan lingkungan sekitarnya (Hakim dalam Aswad, 2004: 63).

Indikator ruang terbuka hijau yang berfungsi sebagai estetika adalah:

a. Lingkungan visual yang menarik

Menarik (attractiveness),

yaitu lingkungan yang menarik dan menyenangkan melalui indera seperti pemandangan, bunyi, bau dan sentuhan.

b. Keberadaan unsur-unsur buatan seperti patung, tugu, dsb yang indah dan menarik

c. Keberadaan unsur alamiah yag terawat dan beragam.

Apabila suatu RTH dapat berfungsi estetis maka manfaat yang dapat dirasakan adalah dapat meningkatkan kenyamanan, memperindah lingkungan kota baik (dari skala mikro: halaman rumah, lingkungan permukiman, maupun makro: lansekap kota secara keseluruhan). Mampu menstimulasi kreativitas dan produktivitas warga kota. Juga bisa berekreasi secara aktif maupun pasif, seperti: bermain berolahraga, atau kegiatan sosialisasi lain, yang sekaligus menghasilkan 'keseimbangan kehidupan fisik maupun psikis'. Dapat tercipta suasana serasi, dan seimbang antara berbagai bangunan gedung, infrastruktur jalan dengan pepohonan hutan kota, taman kota, taman kota pertanian dan perhutanan, taman gedung, jalur hijau jalan, bantaran rel kereta api, serta jalur biru bantaran kali.

\section{Tempat Pemakaman Umum}

Berdasarkan Peraturan Pemerintah Nomor 9 Tahun 1987 tentang penyediaan dan penggunaan tanah untuk keperluan tempat pemakaman. Pengelolaan tanah tempat pemakaman di Indonesia dewasa ini kenyataannya dapat dibedakan dalam beberapa macam, yaitu:

a. Tempat Pemakaman Umum

Tempat Pemakaman Umum dilaksanakan oleh Pemerintah Daerah dan/atau Pemerintah Desa, dimana areal tanah tersebut disediakan untuk pemakaman jenazah bagi seluruh anggota masyarakat dengan tidak membedakan agama, bangsa atau kewarganegaraannya.

b. Tempat Pemakaman Bukan Umum.

Tempat Pemakaman Bukan Umum yang juga disebut Tempat Pemakaman Partikelir pengelolaannya dilakukan oleh swasta dan hanya dimungkinkan oleh suatu Badan Hukum/ Yayasan yang bergerak di bidang sosial dan/atau keagamaan dengan memperhatikan ketentuan-ketentuan yang telah digariskan oleh Pemerintah Daerah.

c. Tempat Pemakaman Khusus.

Di samping Tempat Pemakaman Umum dan Tempat Pemakaman Bukan Umum tersebut di atas, terdapat tempat-tempat pemakaman yang mempunyai nilai sejarah dan budaya seperti pemakaman para Wali 
(Makam Wali Songo), Raja-raja (Pemakaman Imegiri), tempat pemakaman para pahlawan dan pejuang bangsa (Taman Makam Pahlawan) serta tempat pemakaman perang Belanda di tujuh kota sesuai dengan Keputusan Presiden Nomor 30 Tahun 1971.

d. Krematorium.

Tempat pembakaran jenazah atau kerangka jenazah yang pelaksanaannya dilakukan Pemerintah Daerah,masyarakat ataupun Badan Hukum/Yayasan yang bergerak di bidang sosial dan/atau keagamaan dengan memperhatikan persyaratan yang ditetapkan oleh Pemerintah Daerah.

e. Tempat Penyimpanan Jenazah.

Menurut adat yang masih berlaku di berbagai tempat di Indonesia, dikenal beberapa masyarakat hukum adat yang tidak mengubur jenazah di dalam tanah melainkan menyimpan jenazahjenazah di dalam lubang-lubang atau gua-gua ataupun menempatkan jenazah di tempat-tempat yang terbuka, yang karena keadaan alamnya mempunyai sifat-sifat khusus dibandingkan dengan tempat lain.

Berdasarkan pengertian tersebut, penelitian ini dibatasi hanya tempat pemakaman umum yang ada di Kota Pontianak, yaitu:

1. TPU Kristen

TPU Kristen merupakan tempat pemakaman umum yang digunakan untuk memakamkan orang-orang yang pada saat meninggal dunia beragama Kristen. Kawasan pemakaman Kristen yang diamati adalah kawasan pemakaman Kristen yang TPU Kebon Sayur di Kota Pontianak

2. TPU Islam/Muslim

TPU Islam merupakan tempat pemakaman umum yang digunakan untuk memakamkan orang-orang yang pada saat meninggal dunia beragama Islam. Kawasan pemakaman Islam yang diamati adalah kawasan pemakaman Islam yang ada Kota Pontianak kawasan pemakaman itu yaitu: TPU di Sei Bangkong dan TPU di Jl. Putri Candramidi.

3. TPU Tionghoa

TPU Tionghoa merupakan tempat pemakaman umum yang digunakan untuk memakamkan orang-orang yang pada saat meninggal dunia beragama Tionghoa. Kawasan pemakaman Tionghoa yang diamati adalah kawasan pemakaman Tionghoa yang ada Kota Pontianak kawasan pemakaman itu yaitu: TPU Tionghoa di Jalan Khatulistiwa dan TPU Tionghoa di Sungai Raya.

\section{Tempat Pemakaman Umum Dikaitkan dengan Fungsi RTH}

Berdasarkan hasil analisis yang telah dilakukan, masing-masing fungsi RTH tersebut apabila dikaitkan dengan tempat pemakaman umum adalah sebagai berikut:

\section{Fungsi Secara Sosial}

Kawasan pemakaman kristen umumnya mudah dimasuki secara fisik karena letaknya yang berdekatan di tepi jalan sehingga dapat dengan mudah dilalui oleh kendaraan dan orang. Selain itu, sering dijumpai di tempat pemakaman kristen tidak memiliki vegetasi atau pagar pembatas yang dapat menghalangi pandangan orang akan kawasan pemakaman tersebut. Sehingga kawasan pemakaman kristen juga mudah terlihat secara visual

Selanjutnya kawasan-kawasan ini juga dapat dengan mudah dicapai karena letaknya yang strategis dan berdekatan dengan permukiman penduduk serta tidak memiliki penjagaan yang khusus di kawasan-kawasan ini maka jalur untuk memasuki kawasan pemakaman ini juga tidak terbatas. Kejelasan dan keamanan jalur masuk, jalur pejalan, dan tempattempat tujuan pengguna pada kawasan pemakaman kristen relatif cukup baik. Akan tetapi, kawasan pemakaman kristen tidak memiliki landmark sebagai orientasi dan tidak terdapat sebuah penanda yang jelas dari lokasi-lokasi tempat penting atau fasilitas penunjang aktifitas pengguna. Kondisi TPU Kristen dapat dilihat pada gambar 1.

Kawasan pemakaman Islam biasanya terletak di sekitar pemukiman penduduk. Dari segi aksesibilitas TPU Islam biasanya terletak di tepi jalan sehingga sarana transportasi untuk masuk ke dalam kawasan ini relatif mudah dan lancar.(lihat gambar 2) TPU Islam memiliki jalur masuk yang tidak terbatas dan tidak memiliki penjagaan khusus karena kawasan pemakaman Islam walaupun ada yang memiliki pintu gerbang, namun pintu gerbang disini tidak berfungsi sebagai penghalang bagi para pengunjung untuk masuk ke dalam kawasan ini, tapi lebih sebagai penanda masuk ke dalam kawasan pemakaman ini (lihat gambar 2). Kawasan ini merupakan kawasan pemakaman umum sehingga para pengunjung bebas untuk masuk ke dalam kawasan ini. Kawasan pemakaman Islam tidak memiliki landmark. 


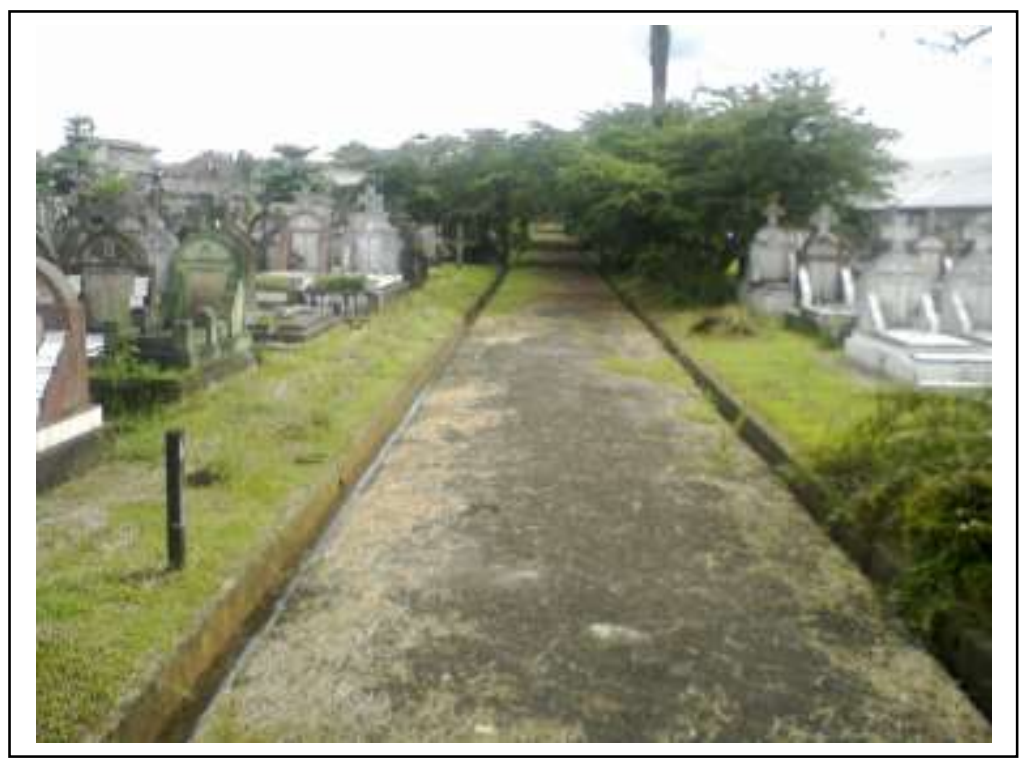

Sumber: (Penulis, 2013)

Gambar 1: TPU Kristen di belakang PSP, Pontianak mempunyai kejelasan jalur masuk, jalur pejalan, dan jalur tempat tujuan pengguna.

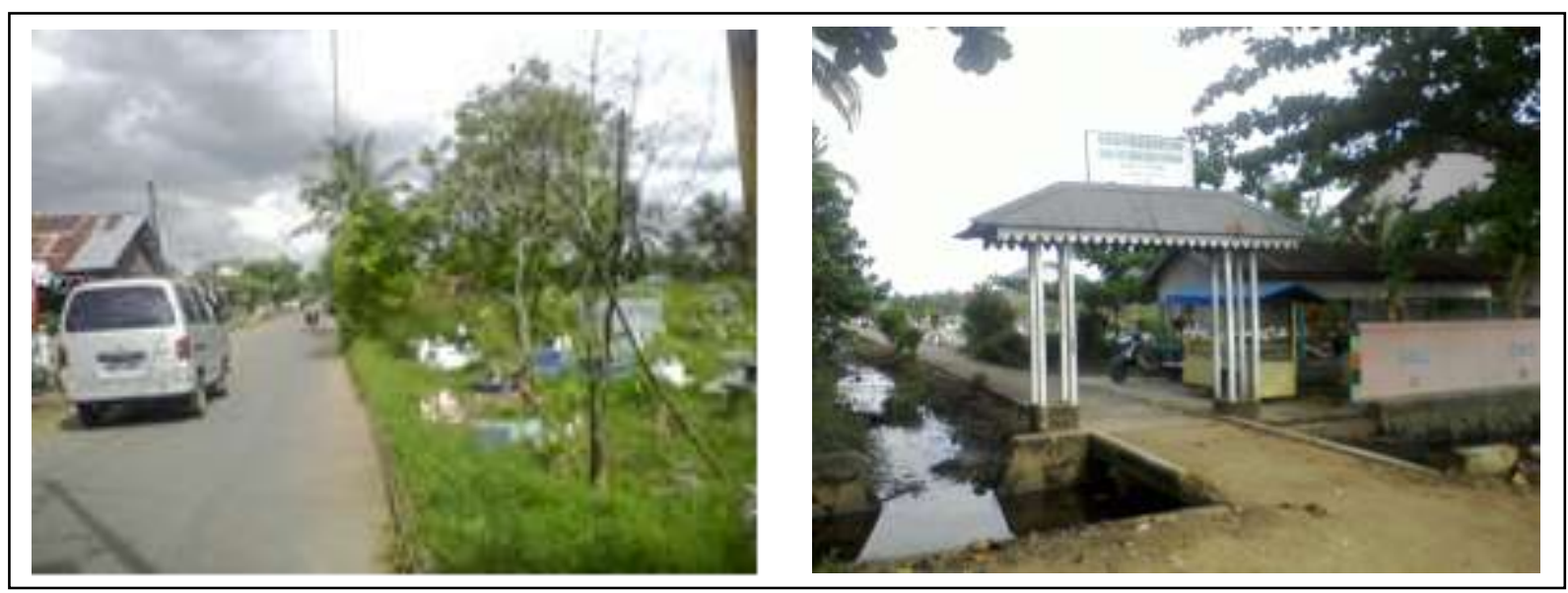

Sumber: (Penulis, 2013)

Gambar 2: TPU Islam Alianyang (Kiri) memenuhi fungsi aksesbilitas RTH dan TPU Islam Danau Sentarum (Kanan) memiliki pintu gerbang sebagai penanda masuk

Kawasan pemakaman Islam telah menyediakan jalan masuk yang mendukung para pengunjung untuk masuk ke kawasan pengguna untuk masuk ke dalam kawasan (lihat gambar 3 )

TPU Islam kurang mendukung jika dilihat indikator keamanan dan kesehatan karena kawasan ini hanya dimanfaatkan untuk kawasan pemakaman saja tanaman yang ada di kawsan ini kurang terawat dengan baik sehingga tidak dapat dimanfaatkan untuk mengurangi polusi udara. sinar matahari, penerangan, dan pengelolaan sampah yang cukup tertangani. Sedangkan air bersih sulit didapat pada kawasan pemakaman ini.

Tidak terdapat fasilitas khusus yang dapat digunakan bagi para pengunjung agar terpenuhinya kebutuhan dasar pengguna, seperti tempat beristirahat, terlindung dari sengatan matahari, tempat berolaharaga, dan sebagainya. Para pengunjung yang ingin memanfaatkan kawasan ini untuk beraktifitas lain tidak disediakan fasilitas penunjang. Dari segi keamanan kawasan pemakaman dapat menciptakan rasa aman bagi para pengunjung. 

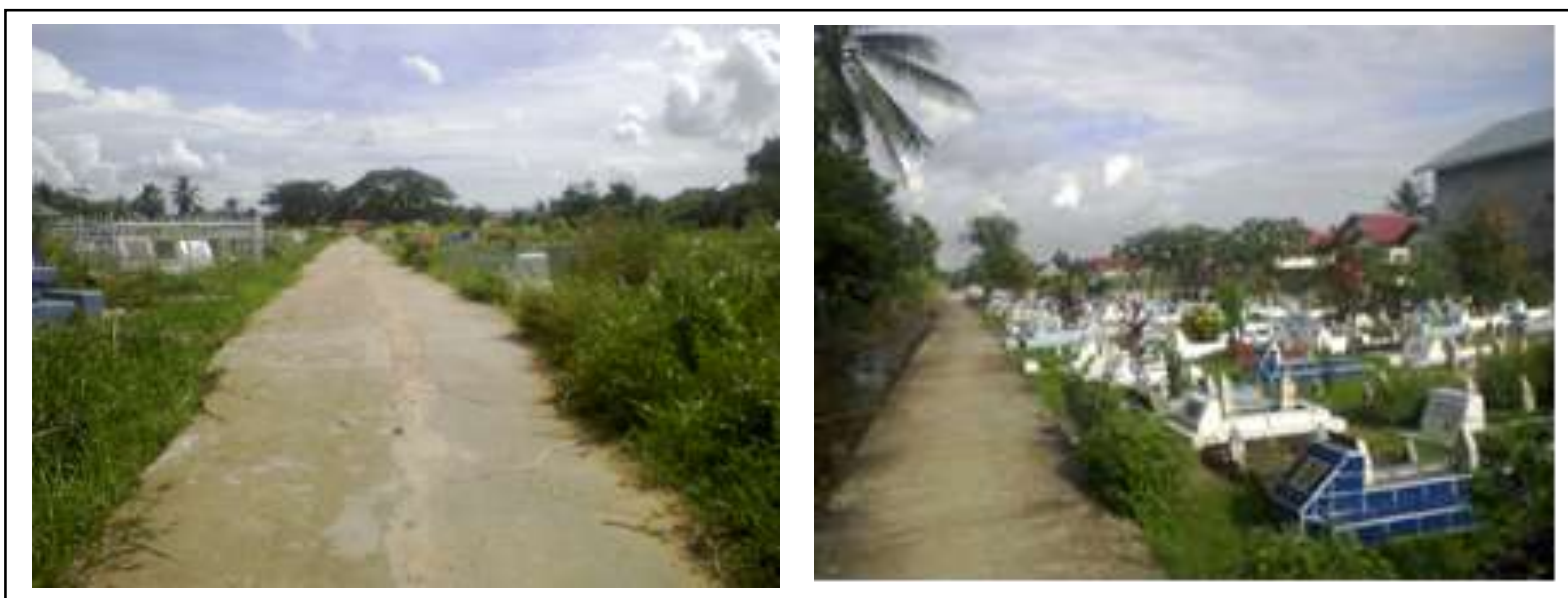

Sumber: (Penulis, 2013)

Gambar 3: TPU Muslim Danau Sentarum terdapat jalan masuk bagi pengunjung pemakaman

Kawasan pemakaman Tionghoa biasanya terletak jauh dari pemukiman penduduk. Dari segi aksesbilitas TPU Tionghoa biasanya terletak di tepi jalan sehingga sarana transportasi untuk masuk ke dalam kawasan ini relatif mudah dan lancar. TPU Tionghoa memiliki jalur masuk yang tidak terbatas dan tidak memiliki penjagaan khusus karena kawasan pemakaman Tionghoa biasanya memiliki pintu gerbang, namun pintu gerbang disini tidak berfungsi sebagai penghalang bagi para pengunjung untuk masuk ke dalam kawasan ini lebih sebagai penanda masuk ke dalam kawasan pemakaman ini. Kawasan ini merupakan kawasan pemakaman umum sehingga para pengunjung bebas untuk masuk ke dalam kawasan ini. Kawasan pemakaman Tionghoa tidak memiliki landmark.Kawasan pemakaman Tionghoa telah menyediakan jalan masuk yang mendukung para pengunjung untuk masuk ke kawasan pengguna untuk masuk ke dalam kawasan ini.

TPU Tionghoa kurang mendukung jika dilihat indikator keamanan dan kesehatan karena kawasan ini sangat sepi dan jauh dari pemukiman sehingga ada kemungkinan orang untuk berbuat jahat, kawasan ini cukup terawat pepohonannya juga cukup banyak. Terdapat fasilitas khusus yang dapat digunakan bagi para pengunjung agar terpenuhinya kebutuhan dasar pengguna, seperti tempat beristirahat, terlindung dari sengatan matahari, , dan sebagainya. Para pengunjung yang ingin memanfaatkan kawasan ini untuk beraktifitas lain disediakan fasilitas penunjang seperti tempat untuk beribadah. Dari segi keamanan kawasan pemakaman dapat menciptakan rasa aman bagi para pengunjung.

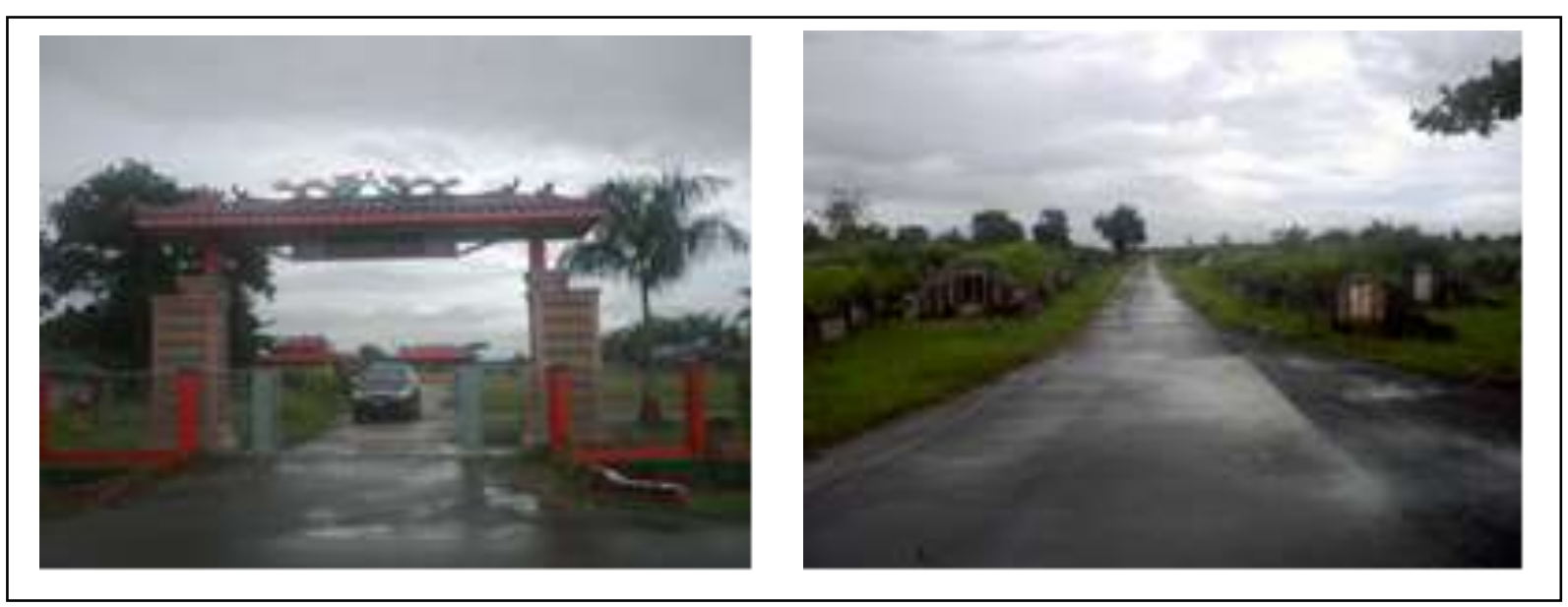

Sumber: (Penulis, 2013)

Gambar 4: Jalur Masuk TPU Tionghoa Jl. Khatulistiwa (Kiri) dan TPU Tionghoa Adisucipto (Kanan) 


\section{Fungsi Secara Fisik}

Kawasan pemakaman kristen pada umumnya telah ditetapkan sebagai kawasan pemakaman melalui peraturan daerah. Pemakaman ini biasanya terdapat pepohonan yang rindang dan beberapa jenis tanaman yang kodisinya relatif baik dan mempunyai tajuk yang tebal sehingga dapat menyerap polutan. Secara keseluruhan pada kawasan-kawasan ini memiliki pepohonan rindang yang mempunyai kerapatan dengan memebentuk formasi. Selain itu, biasanya jenis tanaman yang ada di kawasan pemakaman kristen memiliki dahan dan akar yang kuat serta daun yang tidak mudah gugur oleh terpaan angin dengan kecepatan sedang dan terdapat juga vegetasi yang cukup dapat menyerap air hujan dan memilki cukup banyak tanaman yang berakar serabut yang dapat menyerap volume air lebih banyak sehingga dapat dijadikan sebagai daerah resapan air dan dapat juga menjadi daerah yang dapat mengendalikan banjir bagi daerah sekitarnya.

Di kawasan pemakaman kristen jarang sekali memiliki dinding atau pagar pembatas. Selain itu, karena keadaan lantai kawasan pemakaman kristen jarang sekali menggunakan rumput dan pohonpohon yang ada pun masih tidak teratur letaknya sehingga kawasan ini relatif masih kurang berfungsi sebagai dinding dan lantai.selanjutnya tidak didapati pada kawasan-kawasan pemakaman ini ruangan yang besar yang dapat dibagi-bagi menjadi ruangan yang lebih kecil.

Seperti yang sudah dijelaskan sebelumnya maka pencapaian untuk variabel-variabel fungsi fisik pada umumnya sudah tercapai. Sedangkan untuk pencapaian variabel yang dapat menciptakan koridor dan dapat menciptakan sebuah ruang yang menghubungkan ruang-ruang yang lain belum ditemui.

Jumlah tanaman yang ada di kawasan pemakaman muslim ini relatif banyak namun kondisinya yang tidak dirawat dengan baik menyebabkan kawasan ini tidak dapat mambantu mengurangi polusi udara secara maksimal. Hal ini didukung pula dengan kurangnya pepohonan yang rindang pada kawasan pemakaman ini. Vegetasi yang ada pada kawasan ini lebih banyak didominasi oleh vegetasi rumput.

Kawasan pemakaman ini kurang bisa digunakan sebagai pengendali angin karena kurangnya jumlah tanaman yang memiliki tajuk yang tebal dan daun yang rindang. Kerapatan pepohonan yang ada di kawsan ini kurang diatur dengan baik karena kawasan pemakamannya yang tidak terawat sehingga tidak membentuk formasi yang dapat dimanfaatkan sebagai peredam bunyi. Kawasan pemakaman ini juga didominasi oleh tanaman-tanaman bunga yang tidak memiliki dahan dan akar yang kuat serta daunnya yang mudah gugur sehingga tanaman pada kawasan pemakaman ini tidak dapat dimanfaatkan sebagai pengendali angin dan pengendali banjir.

TPU Islam ini kurang dirawat dan di tata dengan baik sehingga tanaman yang ada di kawasan ini tidak ada yang dapat dimanfaatkan sebagai dinding dan lantai. Kawasan pemakaman ini hanya dimanfaatkan sebagai kawasan pemakaman saja tidak terdapat kegiatan lain di kawasan ini.

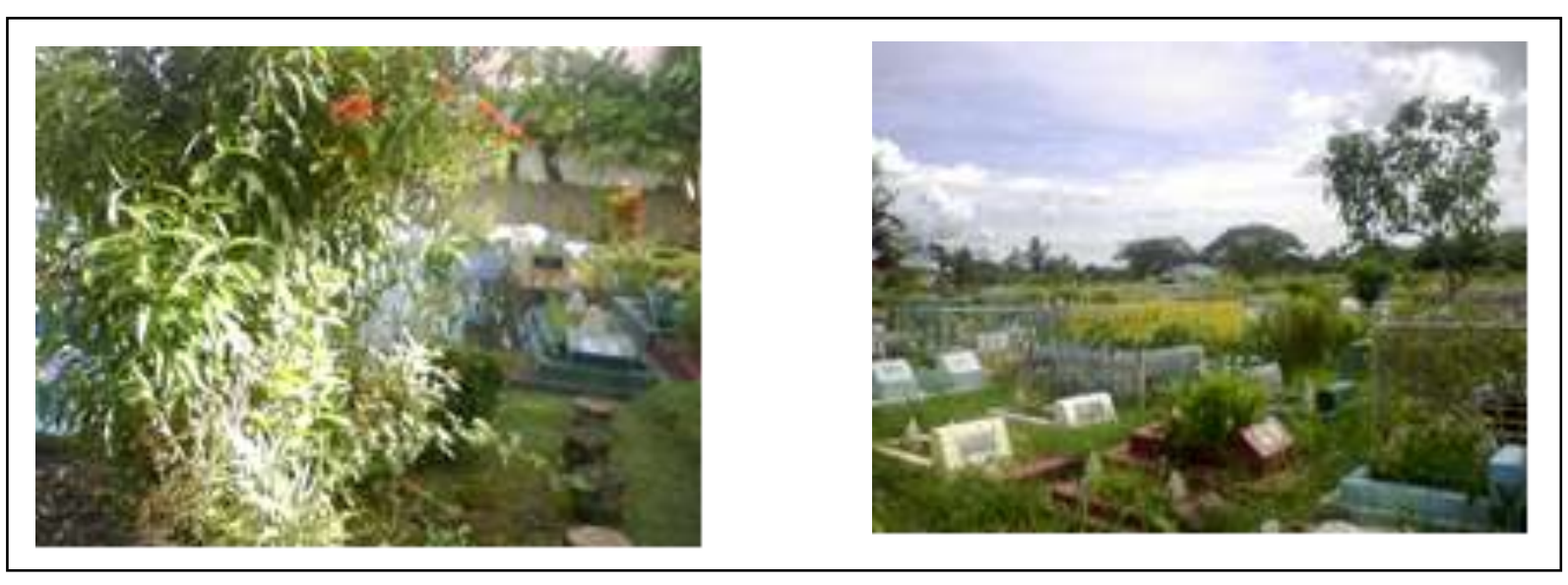

Sumber: (Penulis, 2013)

Gambar 5: Vegetasi di TPU Islam Danau Sentarum

Jumlah tanaman yang ada di kawasan ini relatif banyak namun kondisinya yang tidak dirawat dengan baik menyebabkan kawasan ini tidak dapat mambantu mengurangi polusi udara secara maksimal, tetapi dengan banyaknya pepohonan rindang yang alami kawasan ini dapat menyerap polusi, pengendali bajir, 
pengendali angin tetapi tidak maksimal.

Kawasan pemakaman bisa digunakan sebagai pengendali angin tetapi kurang maksimal karena kurangnya jumlah tanaman yang memiliki tajuk yang tebal dan daun yang rindang. Kerapatan pepohonan yang ada di kawasan ini kurang diatur dengan baik. Karena kawasan pemakamannya yang tidak terawat menyebabkan pepohonannya tidak membentuk formasi yang dapat diamanfaatkan sebagai peredam bunyi.

Kawasan pemakaman ini juga didominasi oleh rerumputan yang tidak memiliki dahan dan akar yang kuat. Hal ini menyebabkan tanaman pada kawasan pemakaman ini kurang maksimal jika dimanfaatkan sebagai pengendali angin dan pengendali banjir.

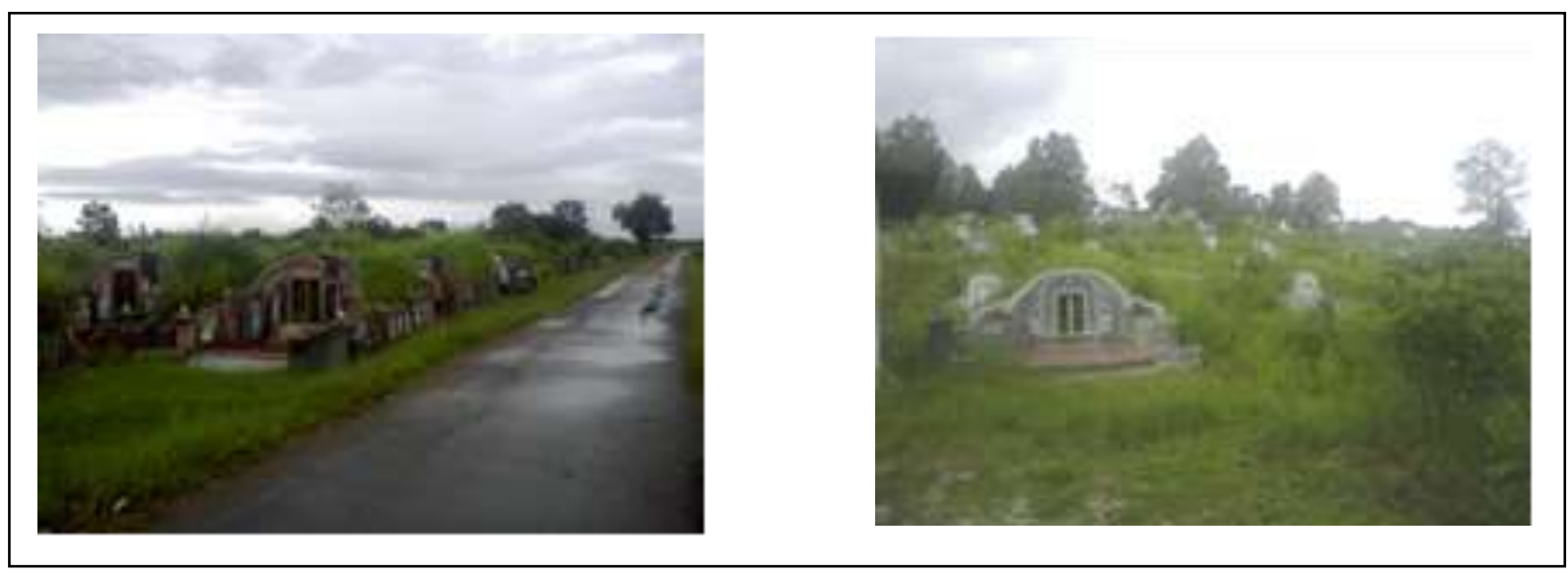

Sumber: (Penulis, 2013)

Gambar 6: Vegetasi di TPU Tionghoa Adisucipto

TPU Tionghoa cukup dirawat dan di tata dengan baik sehingga tanaman yang ada di kawasan ini dapat dimanfaatkan sebagai lantai tetapi tidak bisa dimanfaatkan sebagai dinding karena pepohonannya tidak berbentuk formasi.

\section{Fungsi Secara Estetika}

Kawasan pemakaman kristen pada umumnya memiliki warna tanaman dominan yaitu hijau. Skala atau proporsi tanamannya pun pada umumnya banyak. Tekstur suatu tanaman yang ditentukan oleh batang/percabangannya, massa daun, serta jarak penglihatan terhadap tanaman tersebut masih jarang ditemui. Unsur buatan yang menarik masih jarang ditemui, tapi jumlah dari jenis unsur buatan yang ada tidak mengganggu. Selain dapat memberi fungsi estetis, keberadaan unsurunsur buatan ini dapat memberikan nilai historis. Pada umumnya kondisi dari jenis unsur buatan relatif cukup terawat walaupun kurang beragam. Selain unsur buatan, juga terdapat unsur alamiah. Jumlah dari unsur alamiah yang ada tidak mengganggu dan tidak memiliki fungsi lain selain fungsi estetika. Jenis unsur alamiah yang menarik adalah berupa pemandangan yang indah dari lokasi pemakaman tersebut.
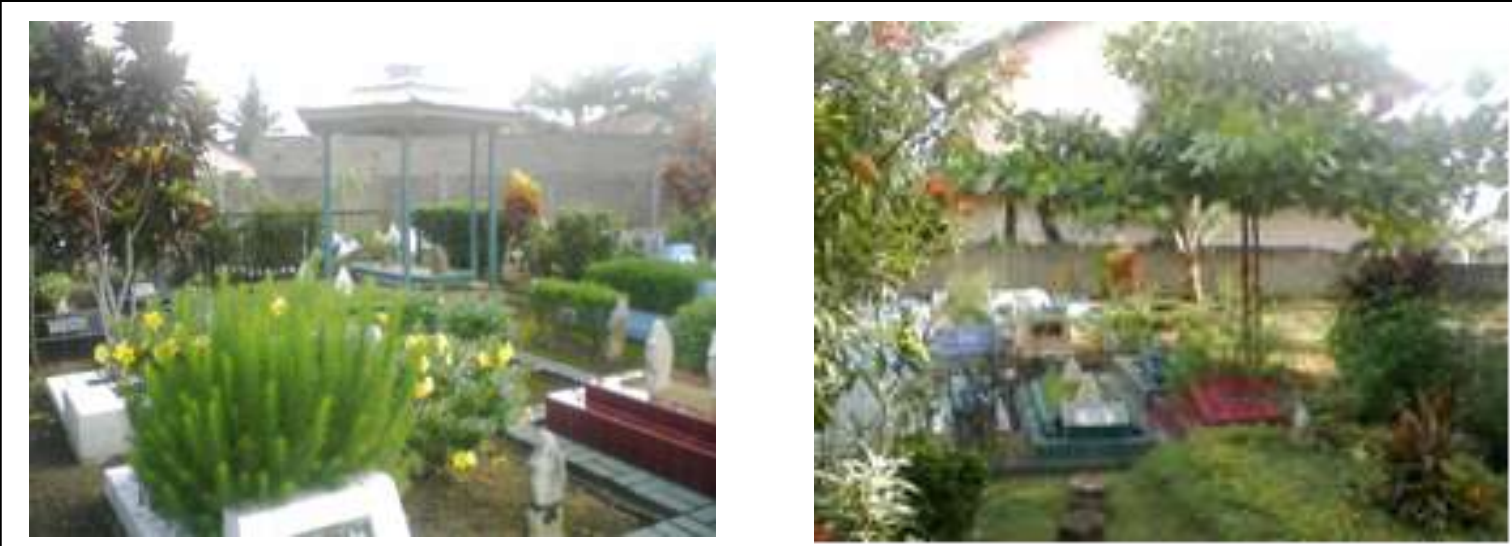

Sumber: (Penulis, 2013)

Gambar 7: Bangun Bangunan di TPU Muslim Danau Sentarum 
TPU Islam tidak memiliki lingkungan visual yang menarik karena kondisi yang tidak terawat seandainya tanaman yang ada kawasan ini bervariasi kemudian diatur dan dirawat dengan baik pastinya akan memunculkan perpaduan warna yang menarik.
Kawasan pemakaman Islam ini tidak memiliki unsur alami dan buatan. Padahal apabila kita melakukan perawatan tanaman dan menanata tanaman itu dengan baik pasti kawasan itu memiliki lingkungan visual yang menarik.

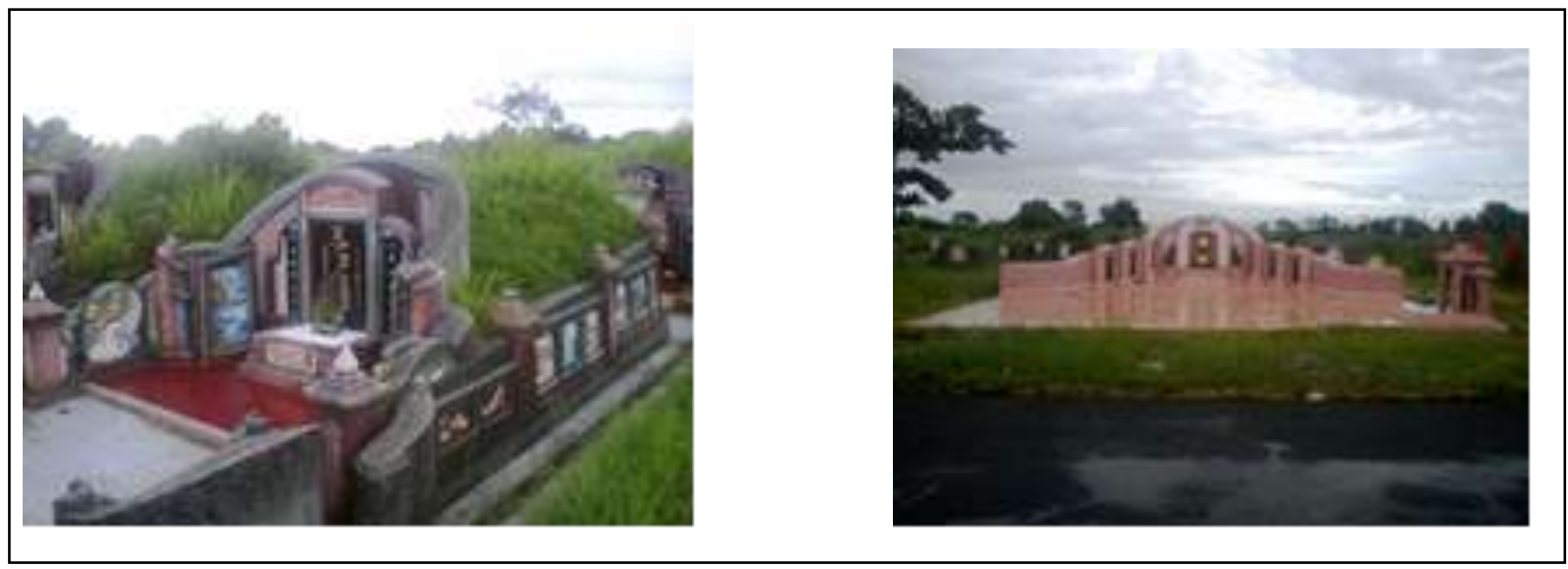

Sumber: (Penulis, 2013)

Gambar 8: Bangun Bangunan di TPU Tionghoa Adisucipto

Unsur buatan di TPU Tionghoa memiliki lingkungan visual yang menarik karena kondisinya yang dirawat tetapi dari unsur alaminya kurang menarik karena kurangnya perawatan. Tekstur tanaman hijau hanya terlihat pada bentuk makam sehingga kesannya lebih banyak unsur buatannya. Kawasan pemakaman Tionghoa ini tidak memiliki unsur alami yang menarik tetapi unsur buatannya cukup menarik. Salah satu contoh unsur estetika di pemakaman ini adalah bangunan makam.

\section{Kesimpulan}

Kawasan pemakaman di Indonesia berpotensi untuk dijadikan RTH jika dilihat berdasarkan fungsi

- Fungsi fisik

Belum ada Tempat Pemakaman Umum (TPU) di Kota Pontianak yang dapat memenuhi fungsi fisik dari Ruang Terbuka Hijau (RTH). Agar dapat memenuhi fungsi fisik RTH tumbuhan pada kawasan ini perlu dirawat dengan baik dan ada petugas khusus yang bertugas untuk merawat makam. Pada kawasan pemakaman juga harus memiliki pepeohonan yang rindang dan beberapa jenis tanaman yang terawat dengan baik.

- Fungsi sosial: TPU Islam,TPU Kristen, TPU Tionghoa

TPU Islam, TPU Kristen, TPU Tiong Hoa merupakan kawasan pemakaman umum sehingga para pengunjung bebas untuk masuk ke dalam pemakaman ini. Kawasan pemakaman ini memenuhi fungsi sosial RTH

- Fungsi estetika: TPU Kristen dan TPU Tionghoa

Tempat Pemakaman Kristen terdapat unsur-unsur buatan seperti patung yang menarik jika dilihat dari fungsi estetika.

\section{Referensi}

Aswad. 2004. Studi Konsep Pengembangan Penataan Ruang Terbuka Hijau di Kawasan Pusat Kota Pangkalan Bun Kalimantan Timur. Jurnal ASPI. Vol 3 , April, 58-79

Departemen Dalam Negeri. 1988. Instruksi Menteri Dalam Negeri Nomor 14 Tahun 1988 tentang Penataan Ruang Terbuka Hijau di Wilayah Perkotaan. Jakarta: Departemen Dalam Negeri

Departemen Dalam Negeri. 2007. Peraturan Menteri Dalam Negeri Nomor 1 Tahun 2007 tentang Penataan Ruang Terbuka Hijau Kawasan Perkotaan. Jakarta: Departemen Dalam Negeri

Sekretariat Negara. 1987. Peraturan Pemerintah Republik Indonesia Nomor 9 Tahun 1987 tentang Penyediaan Dan Penggunaan Tanah Untuk Keperluan Tempat Pemakaman. Jakarta: Sekretariat Negara 